\title{
Population structure and symbiotic relationships of the invasive species Sinanodonta woodiana (Lea, 1834) in water bodies of Ukraine
}

\author{
Tetiana Yermoshyna ${ }^{1, *}$, and Olesia Pavliuchenko ${ }^{1}$ \\ ${ }^{1}$ Zhytomyr Ivan Franko State University, Department of Zoology, Biological Monitoring and Nature Conservation, 40 Velyka \\ Berdychivska Str., Zhytomyr, 10008, Ukraine
}

\begin{abstract}
Understanding the process of penetration and distribution of the invasive species Sinanodonta woodiana is important for predicting associated changes in biodiversity and the structure of freshwater communities. The biomass, density, age and sex structure of mollusk populations were analyzed. An increase in the size of Chinese pond mussels was noted after the introduction: the shell length of individuals from a pond (Romanivka village, 2017) was $24,2 \%$ more than of mollusks from the Velyka Repida river (Matroska village, 2004), and in 2019 it increased by another 14,7\% (by 42,5\% compared to the shell length of the mollusks from the Velyka Repida river). The body weight of $S$. woodiana from the river was 125,3 g, while in the pond there was a 2,13-fold increase in body weight in 2017, with a further increase in this indicator by another $23,6 \%$ in 2019 and another $37,7 \%$ in 2020 . The relative number of $S$. woodiana and native species Unio pictorum and Anodonta anatina in 2017 was 26,3\%, 47,4\% and 26,3\%, in $2020-64,0 \%, 16,0 \%$ and 20,0\% respectively. Ciliates of the genus Conchophthirus and Trichodina, Aspidogaster conchicola, Helobdella stagnalis, larvae of Chironomus sp. are in a symbiotic relationship with $S$. woodiana. The most common Conchophthirus sp. - in 21,6\% of individuals. Further spread of $S$. woodiana to the cold regions of Ukraine and the formation of new populations in the already developed regions should be expected.
\end{abstract}

\section{Introduction}

There is a problem of colonization of territories by invasive species in many countries these days. This is one of the largest environmental problems of our time, which is associated with active processes of biotic globalization.

Invasive species in new habitats, as a rule, do not have natural enemies to control their numbers, which contribute to their rapid spread and a sharp increase in numbers in the newly populated area. Invaders, directly and indirectly, affect native species in natural ecosystems. An invasive species has a direct impact, entering into a relationship of interspecific competition with local species for resources of the same type. As a result, it can suppress or completely displace native species, which leads to a simplification of the structure of the community and a decrease in its resistance to external influences. An indirect influence is associated with a change in the system of evolutionarily formed complex relationships of local organisms with the habitat. The spread of an invasive species in new habitats leads to the disruption of the established biocenotic relationships between native species. An invasive species can bring its symbionts from their native range, where they were originally distributed, and can also acquire local symbionts in a new range [15]. Penetrating new regions, it enters into relationships with local species, negatively affecting the size and structure of their populations, resulting in a reduction in natural biodiversity.

The bivalve freshwater mollusk Sinanodonta woodiana (Lea, 1834) is an invasive species that was introduced into freshwater bodies of Europe in the middle of the last century and continues to colonize new territories. Its original range is in East Asia. However, from the second half of the twentieth century, a rapid expansion of the range of $S$. woodiana began. Due to its ecological features and wide morphological variability [6], this species of unionid mollusks is actively spreading further, as indicated by the constantly growing number of new sites in which $S$. woodiana is found [7-9]. Although this mollusk was previously considered a thermophilic species, it is found both in reservoirs with a changed (due to the discharge of heated waters) and with a constant water temperature. Depending on the temperature of the aquatic environment, only the density of the settlement and the biomass of this species change. Thus, the population density of $S$. woodiana in favorable conditions of existence usually ranges from several to tens of individuals per square meter. In fish ponds, which do not receive heated waters, the population density of the Chinese pond mussel is relatively low - about 4 individuals per $\mathrm{m}^{2}[10]$.

Understanding the process of penetration and distribution of an invasive species is important in

\footnotetext{
* Corresponding author: yermoshyna.t@gmail.com
} 
predicting the associated changes in biodiversity and biocenosis structure. However, at present, information on the symbiotic relationship of $S$. woodiana in the biocenoses of European freshwater bodies, where the mollusk enters, is scarce [11-14].

Our study aimed to study the structure of populations of the species $S$. woodiana introduced into the water bodies of Ukraine and its symbiotic relationship with local species of freshwater fauna of Ukraine.

\section{Material and methods}

\subsection{Study area and sampling}

The material was the authors' collections from the Velyka Repida river (Matroska village, Izmail Raion, Odessa Oblast) (geographic coordinates - N 45³3'43"; E $\left.28^{\circ} 77^{\prime} 70^{\prime \prime}\right)$ in July 2004. Also, the collection of material was carried out in July-August 2017, 2019 and 2020 from a pond in Romanivka village (Berdychivsky Raion, Zhytomyr Oblast) (geographic coordinates N 49 $89^{\prime} 22^{\prime \prime}$; E $\left.28^{\circ} 48^{\prime} 80^{\prime \prime}\right)$. A total of 94 specimens of $S$. woodiana were examined.

The mollusks were collected by hand at a depth of $0,7-$ $2,5 \mathrm{~m}$. The density of their settlement was determined by the site method. The biomass was calculated by weighing live mollusks together with the liquid of the mantle cavity, followed by recalculating the mass per unit of bottom area. The species identification of mollusks was carried out according to generally accepted literary sources [15; 16]. The age of the animals was determined according to the lines of winter growth arrest. The sex of the mollusks was determined by a smear made from the gonad fluid after its opening. Statistical analysis of the data was performed using descriptive statistics and independent samples t-test.

\subsection{Symbiont detection}

The mollusks underwent a complete parasitological dissection with the preparation of temporary preparations of symbionts. The animals inhabiting $S$. woodiana were initially searched for on the surface of the mantle, oral lobes, gills, in the mantle fluid, and then inside internal organs such as the gonads, pericardium, and kidneys.

The prevalence of symbionts was determined as the percentage of infected hosts with a specific species or group of symbionts. The intensity of invasion is an arithmetic mean of the number of parasites per one infected individual of the host. Abundance index - the average number of a particular species or group of parasites in all host individuals (including uninfected ones).

Determination of the systematic affiliation of symbionts was carried out using keys and scientific articles devoted to the taxonomy of the corresponding groups [17-20].

The study of the morphological organization of local species of freshwater fauna was carried out visually by the movement of objects in a drop of water, at magnifications of 40-400 times based on a biological microscope ULAB
XY-B2. The observation was accompanied by photographing using an IS Capture digital camera designed for observation, photographing and video projection of transparent objects in transmitted ordinary light.

\section{Results and discussion}

\subsection{Population structure of S. woodiana}

For the first time in the Ukrainian part of the Danube river basin, the Chinese pond mussel was recorded in 1999 [21], where the species probably entered from Romania, spreading downstream of the Danube. The Velyka Repida river is a left tributary of the Danube, where the collection of mollusks was carried out in 2004 and 2005 (Matroska village, Izmail Raion, Odessa Oblast).

The entry of $S$. woodiana into a pond in the Romanivka village (Berdychivsky Raion, Zhytomyr Oblast), most likely, occurred in 2005 as a result of the release of mollusks glochidia during their temporary maintenance (for two summer months in special cagesbaskets) under conditions natural reservoir. Chinese pond mussels, collected from the Velyka Repida river, got into the pond.

The population density of $S$. woodiana in the Velyka Repida river was 1,8 ind. $/ \mathrm{m}^{2}$, the biomass was $227,1 \mathrm{~g} / \mathrm{m}^{2}$ (Table 1). In the pond, the density of this mollusk during the study ranged from 0,3 to 4,0 ind. $/ \mathrm{m}^{2}$, and the biomass - from 133,5 to $1354,8 \mathrm{~g} / \mathrm{m}^{2}$.

Table 1. Changes in quantitative indicators of $S$. woodiana and its populations

\begin{tabular}{|c|c|c|c|c|c|}
\hline Year & $\begin{array}{c}\text { Shell } \\
\text { length, } \\
\mathbf{m m} \\
(\mathbf{M} \pm \text { SD) }\end{array}$ & $\begin{array}{c}\text { Weight, } \\
\mathbf{g} \\
\mathbf{M} \pm \text { SD) }\end{array}$ & $\begin{array}{c}\text { Median } \\
\text { age }\end{array}$ & $\begin{array}{c}\text { Population } \\
\text { density, } \\
\text { ind./m }\end{array}$ & $\begin{array}{c}\text { Biomass, } \\
\mathbf{g} / \mathbf{m}^{2}\end{array}$ \\
\hline \multicolumn{6}{|c|}{ Velyka Repida river, Matroska village } \\
\hline 2004 & $\begin{array}{c}106,2 \pm \\
8,9\end{array}$ & $\begin{array}{c}125,3 \pm \\
25,7\end{array}$ & 4,3 & 1,8 & 227,1 \\
\hline \multicolumn{6}{|c|}{ Pond, Romanivka village } \\
\hline 2017 & $\begin{array}{c}131,9 \pm \\
6,8\end{array}$ & $\begin{array}{c}267,0 \pm \\
41,6\end{array}$ & 3,6 & 0,5 & 133,5 \\
\hline 2019 & $\begin{array}{c}151,3 \pm \\
4,2\end{array}$ & $\begin{array}{c}330,1 \pm \\
35,1\end{array}$ & 3,9 & 4 & 1354,8 \\
\hline 2020 & $\begin{array}{c}158,6 \pm \\
4,2\end{array}$ & $\begin{array}{c}454,4 \pm \\
35,3\end{array}$ & 3,9 & 0,3 & 145,4 \\
\hline
\end{tabular}

The lower values of these indicators for mollusks from the pond in Romanivka village in 2017 and 2020 may be associated with more severe winter conditions in the north of Ukraine since the water temperature has a direct effect on the growth rate, reproduction and distribution of this species. However, in 2019, we saw a surge in the number of Chinese pond mussels in the local population from a pond in the Pyatygirka river.

Like any invasive species at the stage of conquering new territories, individuals of $S$. woodiana actively reproduce, spread, and, easily winning interspecific competition with native bivalve mollusks for environmental resources, grow rapidly from year to year. 
The average shell length of individuals living in the Velyka Repida river was $106,2 \mathrm{~mm}$, whereas, after introduction into the pond, mollusks significantly increased in length. Thus, the average shell length of individuals collected in 2017 was $24,2 \%$ more $(p<0,01)$ than that of mollusks from the Velyka Repida river, and in 2019 increased by another $14,7 \%$ (by $42,5 \%$ compared with the length of the shell of the Chinese pond mussels from the Velyka Repida). The average shell length of specimens collected in 2020 remained almost unchanged, but the average mass (with shell) continued to grow. Thus, the mass of $S$. woodiana from the river was $125,3 \mathrm{~g}$, while in the pond, a 2,13-fold increase in body weight was noted in $2017(p<0,01)$. In 2019, in mollusks collected from the same local population, this indicator increased by another $23,6 \%$ (Table 1), and in 2020, Chinese pond mussels also increased their body weight by another $37,7 \%$. Although the average age of individuals in this local population in 2019 and 2020 increased slightly to 3,9 years compared to 3,6 years in 2017 , the increase in shell length and body weight was faster. This process is especially noticeable when studying the growth of these parameters in age groups. So, if 2-year-old individuals collected in 2017 and 2019 weigh the same, then by the age of 6 year the body weight gain is more noticeable in individuals collected in 2019 (5,6 times) compared to 2017 (3,9 times). These data indicate that the Chinese pond mussel, thanks to its modification variability, is adapting better and better to new conditions of existence every year.

The age structure of $S$. woodiana populations was studied according to the ratio of age groups - young individuals ( $1-3$ years): average age (4-6 years): older group ( 7 years and older). In populations from two areas, individuals aged from 2 to 8 years were found, in particular, from the Velyka Repida river, 3-8-year-old mollusks were found, and from a pond in Romanivka village - 2-7-year-olds. The age structure consists of representatives of all age groups: the ratio of age groups is $0,8: 1: 0,2$ for mollusks from the Velyka Repida river and $0,9: 1: 0,04$ for Chinese pond mussels from the pond. In both populations of mollusks, the most numerous is the middle age group (from 4 to 6 years old). Young individuals account for a slightly smaller percentage of the total collection. Thus, in the river, 3-year-old mollusks represent $39,5 \%$ of the population of the studied group (Fig. 1), and in the pond, 2- and 3-year-old individuals $45,1 \%$. The smallest is the older group $(2,0-9,3 \%)$. We did not find 1-year-old individuals in two local populations, and 2-year-olds were found only in the Velyka Repida river. The presence of a large number of young individuals in the studied populations of $S$. woodiana indicates its active reproduction.

In the sex-age structure of $S$. woodiana from the Velyka Repida river, the most numerous group among all age groups are 3-year-old males, from the pond - an equally large number of 3- and 4-year-old males and females (Fig. 2). The number of females and males of other age groups is much less.

The sex-age structure in the Velyka Repida river more reflects the invasive nature of the $S$. woodiana species. The presence of a large group of 3-year-old males suggests a growing population in this collection site. In the pond, all age groups are represented relatively evenly, which indicates the sufficient viability of this population and the transition of the Chinese pond mussels from conquering the territory to stable existence in this water body.

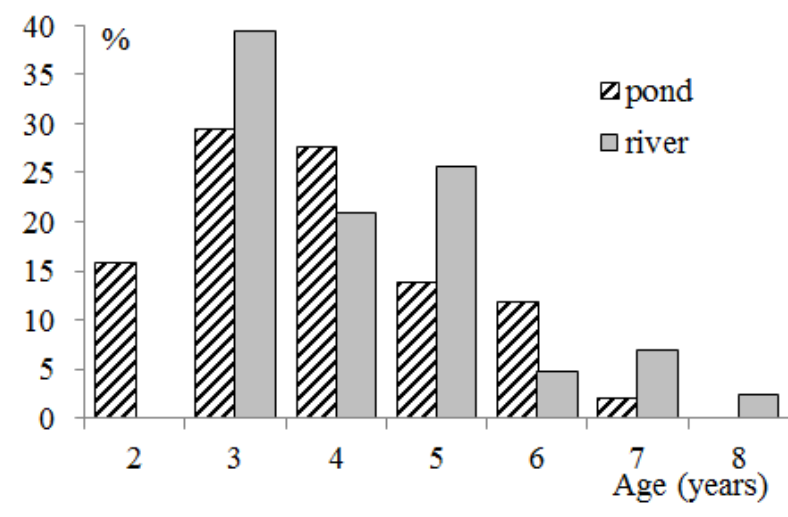

Fig. 1. Age structure of $S$. woodiana population from surveyed biotopes (the ratio of individual age categories to the total number of individuals, \%).

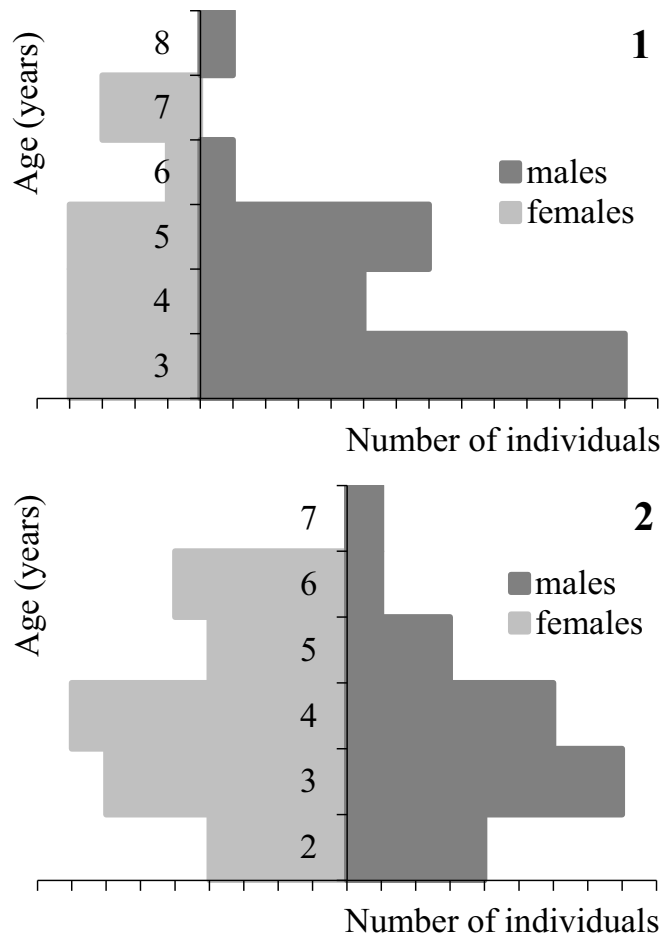

Fig. 2. Sex-age structure of $S$. woodiana population from the studied water bodies: 1 - Velyka Repida river, Matroska village; 2 - pond, Romanivka village.

The sex structure of the population from the Velyka Repida river was dominated by males (female : male ratio is $0,6: 1)$. Whereas in the sex structure of the studied group from the pond, females quantitatively prevailed over males $(1,2: 1)$. This may indicate active reproduction of the invasive species in a new place. Also, almost all females from the pond during the period of collecting the material had a gill pregnancy $(85,7 \%)$, that is, all age groups of mollusks, including 2-year-old individuals, participated in reproduction. The smallest female with glochidia in the gills had a shell length of 
$9,3 \mathrm{~cm}$. That is, even with a slow growth rate of mollusks at the beginning of their life in a reservoir with a natural temperature regime in northern Ukraine, they are capable of reproduction at 2 years of age.

It is known that individuals of $S$. woodiana reach sexual maturity already in the first year of life with a shell length of about $30 \mathrm{~mm}$ [22], while the native Anodonta species reach maturity at 2 years or later [23]. This feature of the reproductive biology of the Chinese pond mussel gives a significant competitive advantage over the local unionid mollusks.

\subsection{Advantages of $S$. woodiana in freshwater biocenoses and its impact on their biodiversity}

One of the key factors in the success of a species invasion is its tolerance to environmental stress. There is ample empirical evidence that invasive species can better tolerate adverse conditions than native species. Thus, researchers have studied the resistance of $S$. woodiana to thermal stress and trace metallic zinc pollution stress. The higher tolerance of this mollusk in stress tests was associated with a significant decrease Rhodamine B accumulation, indicating more efficient multixenobiotic resistance mechanism; with significantly higher INT reduction capacity; with less pronounced changes in the activity of stress-related enzymes (glutathione-Stransferase, catalase) and neurotoxicity biomarker (cholinesterase) [24].

We noted a high variability in the shape and color of shells in $S$. woodiana from the two studied biotopes. The shape of the shells of individuals of the initial population from the Velyka Repida river is most often rounded (the shape of the lower edge of the shell corresponds to a regular semicircle), however, it can be elliptical and irregularly rhombic (the lower edge of the shell forms an obtuse angle). The mollusks from the pond in Romanivka village do not have a rounded shell. The specimens here are usually elliptical, although a third of the specimens have an irregular rhombic shape. An egg-shaped form is occasionally found.

The color of the periostracum of $2 / 3$ of the mollusks of the progenitor population (the Velyka Repida river) is bright green. The rest of the individuals are olive-colored with a small amount of yellow or brown. All individuals from this biotope have pink stripes along the growth lines and vertical green rays. The general background of the periostracum of half of the mollusks from the pond is yellow-green, the second half of the Chinese pond mussels have a darker olive-brown color. The latter variants, as a rule, have a proportion of gray color against the general background of the shell. In all specimens, areas of the periostracum along the growth lines, especially in the lower part, are colored red, and vertical green rays are visible on the shell.

So, the color of shells from the Velyka Repida river is light, bright, while the color of the mollusks from the pond is dominated by a dark general background, which is probably associated with living in very turbid water. Specimens from the Velyka Repida river are more similar in shape and color to typical S. woodiana, while specimens from the pond in Romanivka village resemble mollusks of the genus Anodonta. Such a wide morphological variability of individuals of the Chinese pond mussel is its specific feature, which allows $S$. woodiana to adapt better to different habitats.

Since an invasive species readily adapts to new living conditions, it can rapidly increase the density of the newly formed population and, as a result, threaten native species. We observed such relationships in the investigated pond between $S$. woodiana and two other species of unionid Unio pictorum Linnaeus, 1758 and Anodonta anatina Linnaeus, 1758, which form joint malacofauna. The relative number of $S$. woodiana and native species $U$. pictorum and A. anatina in 2017 was $26,3 \%, 47,4 \%$, and $26,3 \%$, respectively. In 2020 , the ratio of these species in the malacofauna changed and amounted to $64,0 \%, 16,0 \%$ and $20,0 \%$, respectively. However, much earlier, before the Chinese pond mussel appeared in the pond, there were more other mollusks of the Unionidae family: the population density of U. pictorum was 2,1 ind. $/ \mathrm{m}^{2}$, and A. anatina $-1,5$ ind.$/ \mathrm{m}^{2}$. That is, after the introduction of the Chinese pond mussel, the number of local species of unionid mollusks significantly decreased: from 3,6 ind. $/ \mathrm{m}^{2}$ (in 2005) to 0,2 ind. $/ \mathrm{m}^{2}$ (in 2020).

Thus, $S$. woodiana is a large species of bivalve mollusks, which actively assimilates the environment in a new habitat, multiplies intensively, and rapidly increases in size and weight. Due to these features, it can be an attractive settlement site (microbiota) for various freshwater symbionts.

\subsection{Symbiotic relationship of S. woodiana in new biocenoses}

Among the wide variety of interconnections of living organisms in ecosystems, such a type of interspecific relations as symbiosis is distinguished. A symbiotic relationship is a type of close interspecies relationship in which at least one of the species benefits from it. The forms of symbiosis are quite diverse [25]. So, one of the forms is commensalism, in which one of the partners (commensal) imposes on the other (the owner) the regulation of his relations with the external environment and thus receives a certain benefit, without bringing the owner either harm or benefit. Also, a form of symbiosis is parasitism - a form of interspecific relations in which one organism (parasite) exists at the expense of another (the host), repeatedly using it: feeding on its blood, tissues or digested food, and also using it as a temporary or permanent habitat.

Various forms of biological connections between species serve as regulators of the number of living things in a community, determining its stability.

Among the organisms found in association with $S$. woodiana, one can distinguish the group of truly symbiotic organisms for which association with the host is obligatory throughout the life cycle (ciliates of the genus Conchophthirus and Trichodina, Aspidogaster conchicola Baer, 1827) and the group of free-living organisms, which, as a rule, accidentally enter the mantle cavity of the mollusk, but can live there permanently 
(Helobdella stagnalis Linnaeus, 1758, larvae of Chironomus sp.).

Thus, we found the genus Conchophthirus (Oligohymenophorea: Conchophthiridae) typical ciliates to unionid, which are found in aboriginal species from similar biotopes. These ciliates are widespread and occur exclusively in freshwater bivalve mollusks [26]. Ciliates were identified on the gills and in the mantle fluid from the mantle cavity of the $S$. woodiana, where they live and actively move. The prevalence of Conchophthirus $\mathrm{sp}$. in the mantle cavity of the Chinese pond mussels was $21,6 \%$. The body of these ciliates is flat, elliptical, with a mouth near the middle of the body. They have dense cilia over the entire surface and an average length of about 100 microns. Sometimes it can attach to host tissues, especially gills and oral lobes, without causing harmful effects on these tissues. Host age has no effect on invasion by the ciliate Conchophthirus sp. Individuals of age categories from 2 to 6 years old were infected.

We found a parasitic ciliate of the genus Trichodina (Oligohymenophorea: Trichodinidae) on the gills of $S$. woodiana (Fig. 3). The prevalence is insignificant $5,9 \%$. The intensity of the invasion of the Chinese pond mussels was 3,7 specimens per individual. Ciliates of the genus Trichodina from the mantle cavity of mollusks $S$. woodiana have also been identified and described by Chinese researchers [27].

The obligate parasite A. conchicola (Trematoda: Aspidogastridae) is widespread and occurs in all species of the Unionidae family. It has a direct life cycle, which allows it to successfully and quickly enter the symbiocenosis of a species new to the ecosystem. The parasite can complete its life cycle without leaving the mollusk. Adults mature in the pericardial cavity and kidneys, in which they remain to live. In most cases, there were no lesions associated with the vital activity of A. conchicola. However, it can damage host tissue through suction and feeding. Local cellular changes are possible, such as necrosis, metaplasia. Mollusks can encapsulate aspidogasters (encapsulation reaction or granuloma) if they invade tissues [28, 29].

In the examined mollusks, the level of invasion with aspidogasters is low. Thus, the prevalence of these parasites is $13,7 \%$, and the intensity of invasion is 2 specimens. The abundance index is only 0,3 ind. Aspidogasters were found in the pericardium in $71,4 \%$ of the invaded individuals and in the kidney - in $42,9 \%$. Host age does not significantly affect helminth infection. So, individuals of almost all age categories from 3 to 7 years old were infected. However, 2-year-olds were not infected with $A$. conchicola.

Among the facultative symbionts, we identified the two-eyed flat leech H. stagnalis (Clitellata: Glossiphoniidae), which was localized in the mantle cavity of $S$. woodiana. Its body length was $6-10 \mathrm{~mm}$, width was $1-3 \mathrm{~mm}$. The body is short, wide, and flattened dorsally. The front half of the body can stretch strongly. The body is grayish-white, with a large number of brown spots on the dorsal side. A distinctive feature of the species is a brown lenticular plate on the back between the 12th and 13th rings, which is visible through a microscope. Also, this leech has only one pair of eyes that are quite large. The prevalence of this symbiont was $9,8 \%$. The two-eyed flat leech belongs to the organisms of macrozoobenthos, as it lives in stagnant and flowing water bodies on plants and stones, to which it attaches with the help of suckers. It prefers small stagnant overgrown reservoirs. It is $\alpha$-mesosaprobe. The two-eyed flat leech is very mobile and can swim.
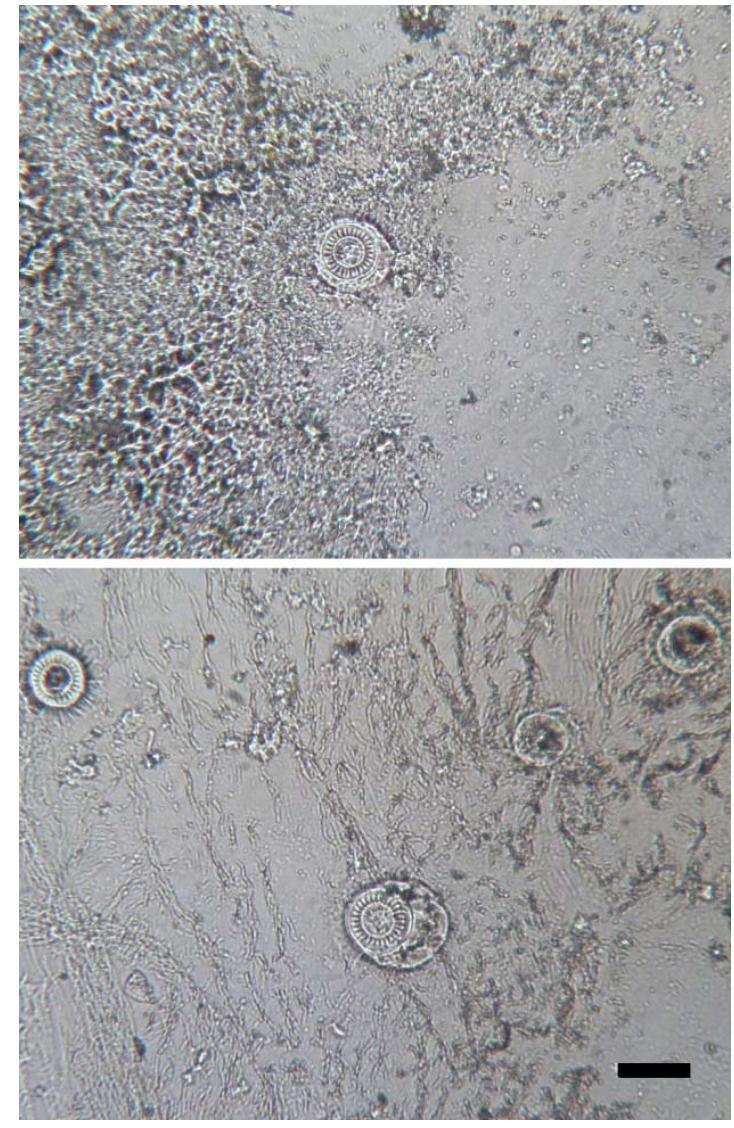

Fig. 3. Trichodina sp. found in the mantle cavity of $S$. woodiana $(\times 200)$. Scale bar: $200 \mu \mathrm{m}$.

We found larvae of Chironomus sp. (Insecta; Chironomidae) between the external gills and the mantle. The prevalence in the studied mollusks is insignificant $3,9 \%$. The intensity of symbiont is minimal -1 specimen per individual. Taking into account the low values of the prevalence and intensity of colonization of the Chinese pond mussels by these organisms, it is possible that they accidentally entered their mantle cavity. However, getting into the mantle cavity, they can exist in association with the mollusk for a long time (this assumption is supported by the fact that the identified above-mentioned free-living organisms were alive and active at the time of the dissection).

So, $45.1 \%$ of the studied individuals of $S$. woodiana from the pond in Romanivka village was inhabited by symbionts. Mixed invasions were observed in $17,4 \%$ of individuals. Other mollusks were inhabited only by representatives of one taxonomic group.

As for the prevalence of symbionts, depending on the age of the mollusk, in 2-year-old specimens of the Chinese pond mussel this indicator is the smallest $(12,5 \%)$ 
among the age groups, and only one symbiont was found in them - the ciliate Conchophthirus sp. (Fig. 4). Almost all symbionts described in the article are found in 3-yearold mollusks and their prevalence in this age group is $53,3 \%$. Only the larvae of Chironomus sp. identified in 4year-old and older individuals. The prevalence of symbionts in 4-year-old $S$. woodiana and older age groups is $42,8-66,5 \%$.

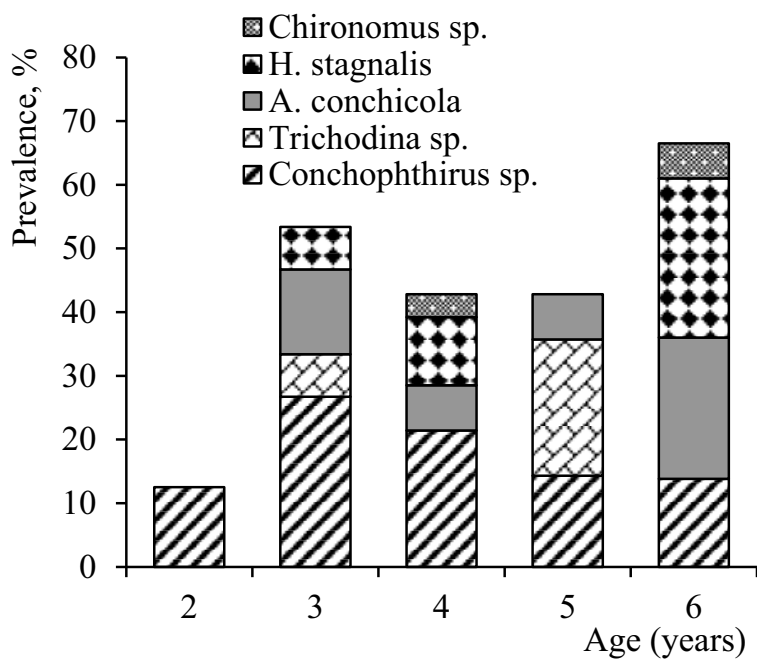

Fig. 4. Prevalence of symbionts in $S$. woodiana.

The large bivalve mollusks $S$. woodiana are an attractive habitat for various freshwater symbionts. This is possible due to the biological characteristics of the species (a large body size and significant biomass in the ecosystem) and its ecological features (resistance to water pollution and oxygen deficiency) [30]. Such hosts provide the best opportunities for symbionts for nutrition, mobility, protection from anxiety, and reduce the risk of predation.

\section{Conclusions}

It was determined that even significant climatic differences between the invasive part of areas (a reservoir with a natural temperature regime in northern Ukraine) and the native part do not create a barrier for the spread of S. woodiana. The low water temperature does not limit the spread of the Chinese pond mussel, which indicates the significant ecological plasticity of this species and the ability to survive and spread in conditions of sufficiently low temperatures. The high percentage of females with gill pregnancy indicates that the development of mollusk larvae under new conditions is close to normal. The presence of a large number of young individuals in the age structure of the population indicates the active reproduction of local populations.

The Chinese pond mussel easily conquers new habitats, where it enters into a variety of biocenotic relationships with local species of freshwater fauna, thereby confirming the stability of its existence in new conditions. Our results show that $S$. woodiana, a species alien to Ukraine, can be inhabited by various groups of symbionts living in Europe. Among the local symbionts in mollusks from a pond in Romanivka village, we noted ciliates Conchophthirus sp., two-eyed flat leech H. stagnalis, larvae Chironomus sp. that enter commensalism with mollusks, Trichodina sp. and A. conchicola, which are parasites of the mollusk. Also, the Chinese pond mussel enters into a relationship of interspecific competition (like any invader species) with local mollusks of the Unionidae family, significantly reducing their numbers. That is, $S$. woodiana can, directly and indirectly, influence the natural biota of the aquatic habitat in the invasive part of the range.

Further spread of $S$. woodiana to the cold regions of Ukraine and the formation of new populations in the already developed regions should be expected.

In the future, we consider it expedient to monitor the state of the $S$. woodiana population from the pond in Romanivka village, to study the annual changes in the age and sex structure, the features of the growth rate of the shell of mollusks and the influence of the invader on the native species of unionid mollusks.

\section{References}

1. D.W. Kelly, R.A. Paterson, C.R. Townsend, R. Poulin, D.M. Tompkins, Parasite spillback: a neglected concept in invasion ecology?. Ecology. 90, 2047-2056 (2009). doi: 10.1890/08-1085.1.

2. M.J. Hatcher, A.M. Dunn, Parasites in ecological communities. From interactions to ecosystems (Cambridge University Press, Cambridge, 2011). doi: 10.1111/sjtg. 12018

3. K. Pulkkinen, T.J. Ruokonen, M. Mykrä, G. Tamb, J. Karjalainen, H. Hämäläinen, Indirect effects of invasive crayfish on native fish parasites. Ecosphere. 4, 50 (2013)

4. C.M. Glodosky, G.J. Sandland, Assessing host competency between native and invasive snail species exposed to the native parasite Echinostoma revolutum. Aquatic Invasions. 9, 87-93. (2014). doi: http://dx.doi.org/10.3391/ai.2014.9.1.07

5. E. Mori, L. Ancillotto, J. Groombridge, T. Howard, V.S. Smith, M. Menchetti, Macroparasites of introduced parakeets in Italy: a possible role for parasite-mediated competition. Parasitol. Res. 114, 3277-81 (2015). doi: 10.1007/s00436-015-4548-2

6. T. Yermoshyna, O. Pavliuchenko, Introduktsiia Sinanodonta woodiana (Bivalvia, Unionidae) $u$ baseini richky Hnylopiat (Zhytomyrska oblast, Pivnichna Ukraina) (Introduction of Sinanodonta woodiana (Bivalvia, Unionidae) in the Hnylop'yat river basin (Zhytomyr oblast, Northern Ukraine)). Visnyk Lvivskoho universytetu. Seriia biolohichna. 79, 132-140 (2018). doi: 10.30970/vlubs.2018.79.14

7. A. Kraszewski, The continuing expansion of Sinanodonta woodiana in Poland and Europe. Folia Malacol., 15, 65-69 (2007). doi: http://dx.doi.org/10.12657/folmal.015.007

8. K. Douda, M. Vrtilek, O. Slavik, M. Reichard, The role of host specificity in explaining the invasion success of the freshwater mussel Anodonta woodiana 
in Europe. Biological Invasions 14, 127-137 (2012). doi: 10.1007/s 10530-011-9989-7

9. J. Lajtner, P. Crnčan, Distribution of the invasive bivalve Sinanodonta woodiana (Lea, 1834) in Croatia. Aquatic Invasions. 6(1) 119-124 (2011). doi: 10.3391/ai.2011.6.S1.027

10. A. Spyra, M. Strzelec, I. Lewin, M. Krodkiewska, A. Michalik-Kucharz, M. Garal, Characteristics of Sinanodonta woodiana (Lea, 1834) populations in fish ponds (Upper Silesia, Southern Poland) in relation to environmental factors. Internat. Rev. Hydrobiol. 97(1), 12-25 (2012)

11. Y. Zhao, F. Tang, Trichodinid ectoparasites (Ciliophora: Peritricha) from Misgurnus anguillicaudatus (Cantor) and Anodonta woodiana (Lea) in China, with descriptions of two new species of Trichodina Ehrenberg, 1838. Systematic Parasitology 67(1), 65-72 (2007). doi: 10.1007/s11230-006-9070-6

12. V. Yuryshynets, N. Krasutska, Records of the parasitic worm Aspidogaster conchicola (Baer 1827) in the Chinese pond mussel Sinanodonta woodiana (Lea 1834) in Poland and Ukraine. Aquat. Invasions. 4(3), 491-494 (2009). doi 10.3391/ai.2009.4.3.9

13. A. Cichy, M. Urbańska, A. Marszewska, W. Andrzejewski, E. Żbikowska, The invasive Chinese pond mussel Sinanodonta woodiana (Lea, 1834) as a host for native symbionts in european waters. J. Limnol. 75(2), 288-296 (2016). doi: 10.4081/jlimnol.2016.1334

14. A. McElwain, Are Parasites and Diseases Contributing to the Decline of Freshwater Mussels (Bivalvia, Unionida)? Freshwater Mollusk Biology and Conservation. 22(2), 85-89 (2019). doi: 10.31931/fmbc.v22i2.2019.85-89

15. P. Glöer, C. Meier-Brook, Süsswassermollusken (DJN, Hamburg, 1998), p. 136.

16. Opredelitel' presnovodnyh bespozvonochnyh Rossii $i$ sopredel'nyh territorij (Key to Freshwater Invertebrates of Russia and Adjacent Lands); pod obshch. red. S.YA. Calolihina. T.6. Mollyuski, Polihety, Nemertiny (Nauka, SPb, 2004), s. 528

17. A. Kahl, Urtiere oder Protozoa. I: Wimpertiere oder Giliata (Infusoria). 4. Peritricha und Chonotricha. (Verlag von Gustav Fisher, Jena, 1935), pp. 653-661

18. K.I. Skryabin, Trematody podklassa Aspidogastrea Faust et Tang, 1936 (Trematodes of the subclass Aspidogastrea Faust et Tang, 1936). In: Trematody zhivotnyh i cheloveka: Osnovy trematodologii. T. 6. (Izd-vo AN SSSR, Moscow, 1952), s. 7-147

19. Z. Raabe, Ordo Thigmotricha (Ciliata-Holotricha). IV. Familiae Thigmophriidae. Acta Protozoologica. IX, 121-170 (1971)

20. Opredelitel' presnovodnyh bespozvonochnyh Rossii $i$ sopredel'nyh territorij (Key to Freshwater Invertebrates of Russia and Adjacent Lands); Pod red. S.YA. Calolihina. T.1. Nizshie bespozvonochnye. (Nauka, SPb, 1994) s. 395
21. V.I. Yurishinets, A.V. Korniushin, Novyj dlya fauny Ukrainy vid dvustvorchatyh mollyuskov Sinanodonta woodiana (Bivalvia, Unionidae), ego diagnostika $i$ vozmozhnye puti introdukcii (The new species in the fauna of Ukraine Sinanodonta woodiana (Bivalvia, Unionidae), its diagnostics and possible ways of introduction). Vestnik zoologii. 35(1), 79-84 (2001)

22. A.M. Labecka, J. Domagala, Continuous reproduction of Sinanodonta woodiana (Lea, 1824) females: An invasive mussel species in a female-biased population. Hydrobiologia. 810, 57- 76 (2018)

23. A. Zieritz, D.C. Aldridge, Sexual, habitat-constrained and parasite-induced dimorphism in the shell of a freshwater mussel (Anodonta anatina, Unionidae). Journal of Morphology. 272, 1365- 1375 (2011)

24. A. Bielen, I. Bosnjak, K. Sepcic, M. Jaklic, M. Cvitanic, J. Lusic, J. Lajtner, T. Simcic, S. Hudina, Differences in tolerance to anthropogenic stress between invasive and native bivalves. Sci Total Environ. 543, 449-459 (2016). doi: 10.1016/j.scitotenv.2015.11.049

25. J.L. Bronstein, Mutualism (Oxford University Press, Oxford, United Kingdom, 2015), p. 315.

26. F. Carella, G. Villari, N. Maio, G. De Vico, Disease and Disorders of Freshwater Unionid Mussels: A Brief Overview of Recent Studies. Front. Physiol. 7, 489 (2016). doi: 10.3389/fphys.2016.00489

27. Y. Zhao, F. Tang, Trichodinid ectoparasites (Ciliophora: Peritricha) from Misgurnus anguillicaudatus (Cantor) and Anodonta woodiana (Lea) in China, with descriptions of two new species of Trichodina Ehrenberg, 1838. Systematic Parasitology. 67(1), 65-72 (2007). doi: 10.1007/s11230-006-9070-6

28. M.K. Huehner, F.J. Etges, Encapsulation of Aspidogaster conchicola (Trematoda: Aspidogastrea) by unionid mussels. J. Invert. Pathol., 37, 123-128 (1981).

29. O.V. Pavliuchenko, T.V. Yermoshyna, Parazyty perlivnytsevykh (Bivalvia, Unionidae) ta yikh vplyv na orhanizm moliuskiv (Parasites of unionid molluscs (Bivalvia, Unionidae) and their effect on the body of molluscs). Regulatory Mechanisms in Biosystems. 8(4), 482-488 (2017). doi: 10.15421/021774

30. L.N. Du, Y. Li, X.Y. Chen, J.X. Yang, Effect of eutrophication on molluscan community composition in the Lake Dianchi (China, Yunnan). Limnologica. 41, 213-219 (2011). doi:10.1016/j.limno.2010.09.006 